\title{
BIOLOGICAL CONTROL OF ANTHRACNOSE OF SOYBEAN
}

\section{Akida Jahan, Nushrat Jahan, Farjana Yeasmin, Mohammad Delwar Hossain and Muhammed Ali Hossain*}

Department of Plant Pathology, Faculty of Agriculture, Bangladesh Agricultural University, Mymensingh-2202, Bangladesh

*Corresponding author: Muhammed Ali Hossain; E-mail: alihossain.bau@gmail.com

\section{ARTICLE INFOABSTRACT}

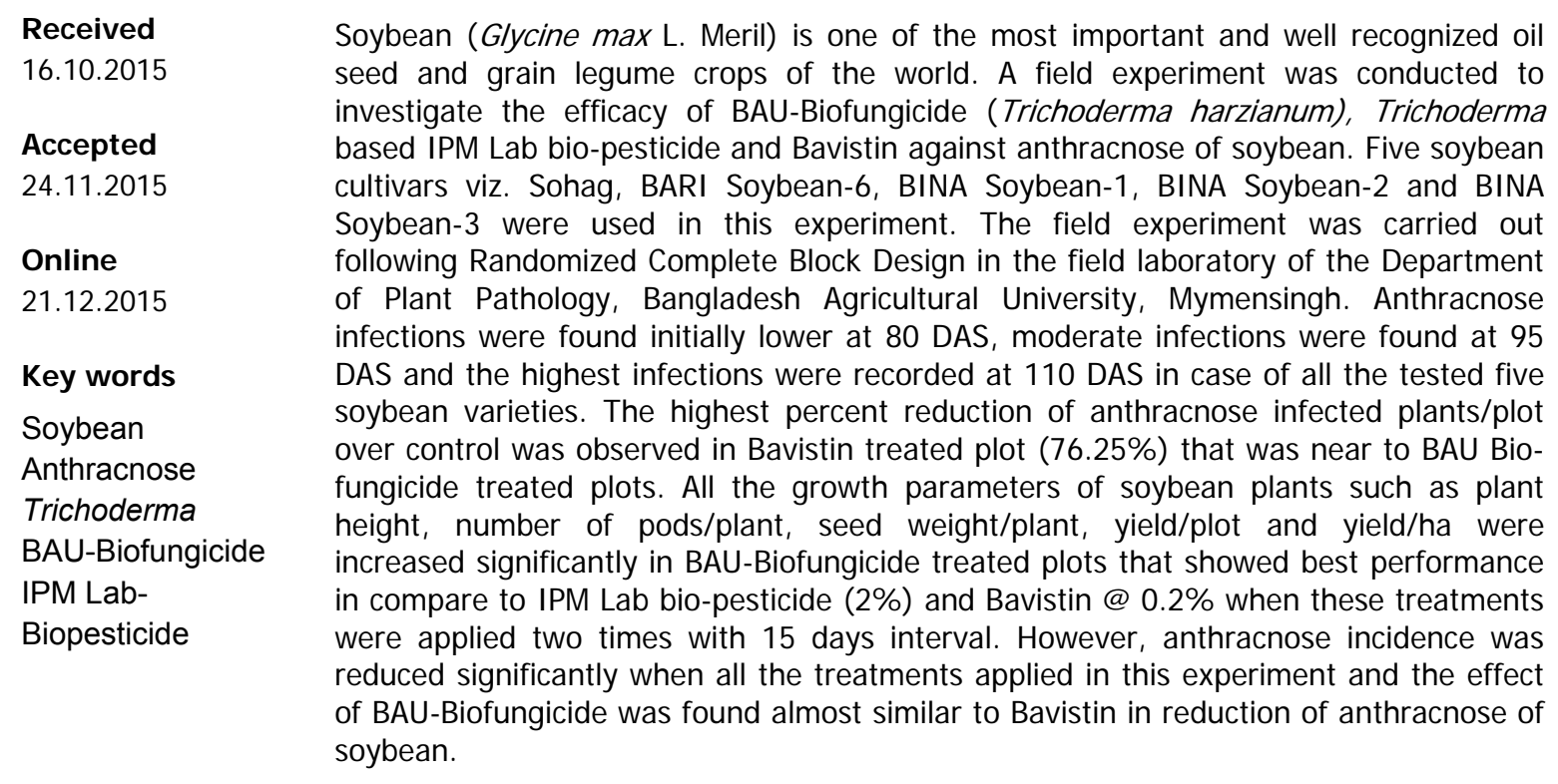

To cite this article: J Akida, Nusrat J, Yeasmin F, Hossain D M and Hossain M A, 2015. Biological control of anthracnose of soybean. Res. Agric. Livest. Fish. 2 (3): 419-426.

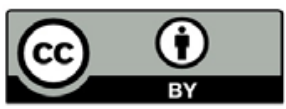

This is an open access article licensed under the terms of the Creative Commons Attribution 4.0 International License

www.agroaid-bd.org/ralf, E-mail: editor.ralf@gmail.com 


\section{INTRODUCTION}

Soybean is called the "golden bean" or "Miracle bean" or "Protein hope of future" because of its high nutritive value. It is a major food and feed source that mainly cultivated for high-quality oil (20\%) and high protein content (40\%) (Napoles et al., 2009, Osho, 2003). Two essential fatty acids namely linoleic and linolenic are found in soybeans, aid in the body's absorption of vital nutrients, and regulate smooth muscle contraction, blood pressure and the growth of cells. It can meet up minerals like $\mathrm{Ca}$ and $\mathrm{P}$ including vitamin $\mathrm{A}$, B, C, D and other different nutritional needs (Rahman, 1982). A variety of soya products as food such as soya dal, soya chatni, soya khichuri, soya milk, soya curd, soya flour, soya meat and roasted soybean snacks are becoming familiar (Osho, 2003). Moreover, Soybean root nodules contain Rhizobium, which fixes atmospheric nitrogen and enriches soil fertility. The nodule soybean can fix $94 \mathrm{Kg}$ nitrogen in a hectare in one season (Satter, 2001).

Soybean was domesticated in the eleventh century BC around northeast China (Hymowitz and Shurtleff, 2005) with satisfactory yield. But, due to lack of suitable climatic conditions, the yield of soybean is very low in Bangladesh. The average yield of soybean is about $3.0 \mathrm{t} \mathrm{ha}^{-1}$ in the world, whereas the yield of soybean is only 2-2.25 $\mathrm{t} \mathrm{ha}^{-1}$ in Bangladesh (SAIC, 2007). The lack of high yielding as well as the lack of pest and disease resistance varieties are the main causes for the lower yield of soybean at farmers' level in Bangladesh. All parts of soybean plant are susceptible to a number of pathogens which reduce quality and/or quantity of seed yield. Soybean suffers nearly from 150 different diseases (Sinclair, 1994) and 51 out of 150 are identified as seed borne diseases, 26 diseases out of 51 seed borne diseases are known to be transmitted through seed (McGee, 1992). Among the seed born diseases of soybean, anthracnose caused by Colletotrichum dematium var truncatum is the most serious fungal disease. This $C$. dematium var truncatum fungus can cause severe damage of soybean by reducing seed yield and quality in warmer, tropical and sub-tropical regions of the world (Sinclair, 1994).

Since Colletotrichum dematium var truncatum is increasingly destructive in oil production of soybean, ways of controlling the disease need to be developed resistant varieties are required to stabilize seed production and to promote sustainable agriculture without hazardous chemical control. But it's very difficult, laborious, costly and time consuming to developed a resistant variety against Colletotrichum dematium var truncatum. Hence, the introgression of biological agent for the control of anthracnose of soybean is the only viable way for the long term control of this disease and save the nature as well as getting balanced the environment from the hazardous effect of fungicides.

\section{MATERIALS AND METHODS}

The experiment was conducted in the Department of Plant Pathology and in the field laboratory of Bangladesh Agricultural University during November'14 to April'15 following a Randomized Complete Block Design (RCBD) with three replications. Soybean variety Sohag $\left(\mathrm{V}_{1}\right)$, BARI Soybean-6 $\left(\mathrm{V}_{2}\right)$, BINA Soybean-1 $\left(V_{3}\right)$, BINA Soybean-2 $\left(V_{4}\right)$, BINA Soybean-3 $\left(V_{5}\right)$ was used in the experiment. The seeds of Sohag and BARI Soybean-6 were collected from Regional Oil Research Center, Bangladesh Agricultural Research Institute (BARI) Joydebpur, Gazipur and seeds of BINA Soybean-1, BINA Soybean-2 and BINA Soybean-3 were collecyed from Bangladesh Institute of Nuclear Agriculture (BINA), Mymensingh. Six treatments viz. $\mathrm{T}_{0}=$ Control, T 1 = IPM Lab Bio-Pesticide @ 2\%, 1 spray, T 2 = IPM Lab Bio-Pesticide @ 2\%, 2 spray, T = BAU Bio Fungicide @ 2\%, 1 spray, T $4=$ BAU Bio Fungicide @ 2\%, 2 spray and $T_{5}=$ Bavistin @ 0.2\%, 2 spray (used as a positive control) were assessed in this experiment. BAU-Biofungicide and Trichoderma harzianum were collected from the Eco-friendly Disease Management Laboratory and IPM Lab, Department of Plant Pathology, Bangladesh Agricultural University, respectively.

The PDA media was prepared according to Islam (2009) and poured in $500 \mathrm{ml}$ glass bottles and sterilized in an autoclave at $121^{\circ} \mathrm{C}, 15 \mathrm{PSI}$ for $15 \mathrm{~min}$. The media were acidified with 30 drops of $50 \%$ lactic acid per $250 \mathrm{ml}$ medium to avoid the contamination of bacteria. It was then cultured on the same medium for multiplication through incubation at room temperature. Ten PDA plates of 7 days old culture were taken. Two $\mathrm{g}$ of Trichoderma harzianum was added to $100 \mathrm{~mL}$ water to make the concentration $2 \%\left(10^{6} \mathrm{cFu} / \mathrm{ml}\right)$. About $2.5 \mathrm{ml}$ of Tween-20 was added for uniform mixing of Trichoderma spores in the suspension. BAU-Biofungicide 
$(20 \mathrm{~g})$ was taken in a $1000 \mathrm{ml}$ beaker and water was added up to the mark. The material was filtered through cheese cloth. The filtrated liquid was used as $2 \%$ BAU-Biofungicide solution. Then two $\mathrm{g}$ of Bavistin was taken in a beaker and $1000 \mathrm{ml}$ of water was added up to the mark. The material was then stirred properly with the help of a spoon. As a result, $0.2 \%$ Bavistin solution was prepared.

The field was prepared properly with the application of fertilizer and manure at recommended rate. The size of the unit plot was $2.0 \mathrm{~m} \times 1.5 \mathrm{~m}$. Plot to plot distance was $40 \mathrm{~cm}$. Row to Row distance was $40 \mathrm{~cm}$ and plant to plant distance was $5 \mathrm{~cm}$. Seeds of 5 different soybean varieties were sown in lines at about $5 \mathrm{~cm}$ depth on the $19^{\text {th }}$ November, 2014. Tricho-suspension, BAU-Biofungicide and Bavistin were sprayed at 15 days interval during 3 February, 18 February, 2015, respectively. Different intercultural operations likeshading, irrigation, gap filling, weeding and insecticides spray were done timely.

Five plants were randomly selected from each plot for recording data Plant height $(\mathrm{cm})$, No. of infected leaves/plant, Total no. of infected plants /plot, Total no. of pods/plant, No. of infected pods/plant, Seed weight/plant $(\mathrm{g})$, Yield/plot $(\mathrm{kg})$, Total yield (ton ha- $\mathrm{h}^{-1}$. The visual symptoms of anthracnose were critically observed and infected plants were identified comparing the symptoms with those of Commonwealth Mycological Institute (CMI) description. The incidence of anthracnose was recorded thrice at 80, 95 and 110 days after sowing (DAS). The incidence of anthracnose was calculated by following the formula (Ansari, 1995):

No. of infected plants /plot

Disease Incidence $(\%)=\frac{\text { Total number of plants /plot }}{-}$.
Collected data were analyzed by Mstat-c and minitab 15 statistical softwares.

\section{RESULTS AND DISCUSSION}

\section{Symptoms and causal organism}

Symptoms were typically appeared during the early reproductive stage on pods as irregular shaped, brown areas and resembled pod blight. In late reproductive stage, infected tissues were covered with black fruiting bodies (acervuli) that produced minute black spines (setae) that could be seen with the unaided eyes. The setae are diagonistic for preliminary identification of the pathogen. The most common pathogen associated with anthracnose was Colletotrichum dematium var truncatum. Colletotrichum dematium var truncatum was characterized by crowded, black acervuli borne on well-developed stroma. The acervuli were oval to elongate, hemi-spherical to truncate conical in shaped with numerous black, needle like, intermixed long and short setae. The infected pods were used according to Botta et al. (1994) for the identification of Colletotrichum dematium var truncatum.

\section{Effect of different varieties on the growth, disease incidence of anthracnose and yield of soybean}

\section{Plant height}

In this experiment, among the five soybean varieties the tallest variety was found BINA Soybean-3 $(67.94 \mathrm{~cm})$ followed by BINA Soybean-1 $(62.35 \mathrm{~cm})$. BINA Soybean-2 was found the most dwarf variety among the five varieties $(35.25 \mathrm{~cm})$ (Table 1$)$.

\section{Number of pods/plant}

There was a significant variation among the varieties in respect of number of pods/plant shown in Table 1. The highest number of pod was recorded in BINA Soybean-1 (30.34) and the lowest no. of pods/plant was observed in BINA Soybean-2 (25.48) (Table 1). 
Table 1. Effect of varieties on the growth and development of soybean against anthracnose

\begin{tabular}{|c|c|c|c|c|c|c|c|c|c|}
\hline \multirow[t]{2}{*}{ Vaiety } & \multirow{2}{*}{$\begin{array}{l}\text { Plant height } \\
\text { (cm) }\end{array}$} & \multirow{2}{*}{$\begin{array}{l}\text { No. of pod/ } \\
\text { Plant }\end{array}$} & \multirow[t]{2}{*}{ Infection (\%) } & \multicolumn{3}{|c|}{ Pod infection (\%) } & \multirow{2}{*}{$\begin{array}{l}\text { Seed } \\
\text { wt./plant } \\
2.44 \text { (q) }\end{array}$} & \multirow{2}{*}{$\begin{array}{l}\text { Yield/plot } \\
\text { (kg) }\end{array}$} & \multirow{2}{*}{$\begin{array}{l}\text { Total yield } \\
\text { (ton ha-1) }\end{array}$} \\
\hline & & & & 80DAS & 95DAS & 110DAS & & & \\
\hline Sohag & 56.00 & 29.49 & 39.28 & 9.51 & 12.7 & 16.23 & 4.35 & 0.33 & 2.18 \\
\hline BARI Soybean-6 & 55.89 & 25.24 & 33.62 & 10.24 & 13.48 & 19.47 & 5.92 & 0.44 & 2.96 \\
\hline BINA Soybean-1 & 62.35 & 30.34 & 28.16 & 7.76 & 10.15 & 12.16 & 8.64 & 0.65 & 4.32 \\
\hline BINA Soybean-2 & 35.25 & 25.48 & 31.01 & 13.09 & 17.04 & 23.18 & 6.93 & 0.52 & 3.45 \\
\hline BINA Soybean-3 & 67.94 & 27.43 & 33.18 & 11.35 & 13.75 & 18.08 & 7.74 & 0.58 & 3.87 \\
\hline $\operatorname{LSD}_{(0.05)}$ & 0.902 & 0.111 & 2.44 & 0.774 & 0.959 & 0.384 & 0.018 & 0.002 & 0.032 \\
\hline
\end{tabular}

Table 2. Effect of treatments on the growth and development of soybean against anthracnose

\begin{tabular}{|c|c|c|c|c|c|c|c|c|c|}
\hline \multirow[t]{2}{*}{ Treatment } & \multirow{2}{*}{$\begin{array}{l}\text { Plan height } \\
(\mathrm{cm})\end{array}$} & \multirow{2}{*}{$\begin{array}{l}\text { No. of pod/ } \\
\text { Plant }\end{array}$} & \multirow[t]{2}{*}{ Infection (\%) } & \multicolumn{3}{|c|}{ Pod infection (\%) } & \multirow{2}{*}{$\begin{array}{l}\text { Seed } \\
\text { wt./plant } \\
\text { (g) }\end{array}$} & \multirow{2}{*}{$\begin{array}{l}\text { Yield/plot } \\
\text { (kg) }\end{array}$} & \multirow{2}{*}{$\begin{array}{l}\text { Total yield } \\
\text { (ton ha-1) }\end{array}$} \\
\hline & & & & 80DAS & 95DAS & 110DAS & & & \\
\hline $\mathrm{T}_{0}$ (Contol) & 45.40 & 12.04 & 54.62 & 21.84 & 29.25 & 50.61 & 3.29 & 0.25 & 1.65 \\
\hline $\begin{array}{l}\mathrm{T}_{1} \text { (IPM Lab Biopesticide } \\
@ 2 \%, 1 \text { spray) }\end{array}$ & 50.83 & 18.47 & 43.66 & 14.78 & 19.15 & 21.24 & 4.05 & 0.30 & 2.04 \\
\hline $\begin{array}{l}\mathrm{T}_{2} \text { (IPM Lab Biopesticide } \\
\text { @ 2\%,2spray) }\end{array}$ & 62.03 & 34.71 & 28.31 & 5.94 & 7.18 & 7.75 & 9.02 & 0.68 & 4.51 \\
\hline $\begin{array}{l}\mathrm{T}_{3} \text { (BAU-Biofungicide @ } \\
2 \%, 1 \text { spray) }\end{array}$ & 52.07 & 25.69 & 38.34 & 11.42 & 14.33 & 15.78 & 5.16 & 0.38 & 2.58 \\
\hline $\begin{array}{l}\mathrm{T}_{4} \text { (BAU-Biofungicide @ } \\
2 \%, 2 \text { spray) }\end{array}$ & 67.22 & 45.17 & 20.42 & 3.83 & 5.05 & 5.64 & 11.41 & 0.85 & 5.71 \\
\hline $\begin{array}{l}\mathrm{T}_{5} \text { (Bavistin @2\%, } 2 \\
\text { sapray) }\end{array}$ & 55.37 & 29.46 & 12.97 & 4.55 & 5.71 & 5.92 & 7.34 & 0.55 & 3.64 \\
\hline $\operatorname{LSD}(0.05)$ & 0.988 & 0.121 & 1.224 & 0.847 & 1.051 & 0.420 & 0.019 & 0.002 & 0.035 \\
\hline
\end{tabular}


Incidence

The effects of different soybean varieties on the disease incidence were found statistically significant (Table 1). The highest plant infection $(39.28 \%$ ) was found in the variety of Sohag and the lowest incidence was found in BINA Soybean-1 (28.16\%).

\section{Pod infection}

The effects of different soybean varieties on percent infected pods/plant were observed significantly at 80 days after sowing (DAS), 95 DAS and 110 DAS (Table 1). At 80 DAS, the highest infection of pod was recorded in BINA Soybean-2 (13.09\%) and the lowest pod infection was observed in BINA Soybean-1 (7.76\%). Percent pod infection was increased at 95 DAS compared to 80 DAS ranged from 10.15\% (BINA Soybean-1) to $17.04 \%$ (BINA Soybean-2) and the highest percent of pod infection was observed at 110 DAS (Table 1). At 110 DAS, the highest pod infection was recorded maximum in BINA Soybean-2 $(23.18 \%)$ and minimum infection was in BINA Soybean-1 (12.16\%) (Table 1).

\section{Seed weight/plant, Yield/plot and Yield/ha}

Seed weight per plant, yield/plot and yield/hectare were significantly influenced by different varieties. The maximum seed weight/plant $(8.64 \mathrm{~g})$, yield/plot $(0.52 \mathrm{~kg})$ and total yield $\left(4.32\right.$ ton $\left.\mathrm{ha}^{-1}\right)$ were found in the variety BINA Soybean-1. On the other hand, the minimum seed weight/plant $(4.35 \mathrm{~g})$, yield/plot $(0.33 \mathrm{~kg})$ and total yield $\left(2.18\right.$ ton $\left.\mathrm{ha}^{-1}\right)$ were obtained from the variety Sohag (Table 1).

These findings are in accordance with BINA Annual report (2011-2012) where they reported that BINA Soybean-1 gave the higher production than BARI Soybean- 6 in case of yield/ha in every trial at different places (Mymensingh, Rangpur and Magura) in Bangladesh and BINA website where they stated that BINA Soybean-3 is taller than BINA Soybean-1 and BINA Soybean-2 is the most dwarf variety of soybean. Again it stated that BINA Soybean-1 has the higher yield potential than both BINA Soybean-2 and BINA Soybean-3.

\section{Effect of treatments on the growth, and development of different agronomic characteristics of soybean against anthracnose were discussed in Table-2.}

\section{Plant height}

A significant variation of plant height was found in soybean varieties in respect to different treatments (Table 2). The highest plant height $67.22 \mathrm{~cm}$ was recorded in the plots where BAU-Biofungicide was sprayed two times followed by the plots sprayed two times with IPM Lab Biopesticide $(62.03 \mathrm{~cm})$.

\section{Number of pods/plant}

The highest number of pod (45.17) was found in the plots where BAU-Biofungicide was sprayed two times followed by the plots sprayed two times with IPM Lab Biopesticide (34.71). The moderate no. of pods/plant was recorded in the plots treated by Bavistin (29.46) followed by the plots sprayed one time with BAUBiofungicide (25.69) and the plots sprayed one time with IPM Lab Biopesticide (18.47). However, the lowest no. of pod was recorded in control plots (12.04) (Table 2).

\section{Plant infection}

Significantly the highest plant infection was found in $\mathrm{T}_{0}$ (control) $(54.52 \%)$ and the lowest plant infection was found in treatment $T_{5}$ (Bavistin @ 0.2\%) (12.97\%) which was followed by two spraying of BAU Biofungicide @ 2\% (20.42\%) (Table 2).

\section{Percent Pod infection}

The maximum percent pod infection found in control plot and the values were $50.61 \%$ at 110 DAS, $29.25 \%$ at 95 DAS and $21.84 \%$ at 80 DAS. The minimum infection was recorded in BAU-Biofungicide two sprayed plots (at 80 DAS-3.83\%, at 95 DAS-5.05\% and 110 DAS-5.64\%) (Table 2). 


\section{Seed weight/plant, yield/plot and yield/ha}

The maximum seed weight/plant $(11.41 \mathrm{~g})$, yield/plot $(0.85 \mathrm{~kg})$ and yield/ha $(5.71$ ton ha-1) were obtained in the plot where BAU-Biofungicide @ 2\% was sprayed two times followed by IPM Lab Biopesticide @ 2\%, 2 spray $\left(9.02 \mathrm{~g}, 0.68 \mathrm{~kg}\right.$ and $4.51 \mathrm{ton} \mathrm{ha}^{-1}$, repectively). The lowest values of seed weight/plant $(3.29 \mathrm{~g})$, yield $/$ plot $(0.25 \mathrm{~kg})$ and yield $/ \mathrm{ha}\left(1.65\right.$ ton $\left.\mathrm{ha}^{-1}\right)$ was found in control plots (Table 2).

These findings are in an accordance with the findings of Hasan (2012) who stated that BAU-Biofungicide gave higher plant height, maximum weight of pods/plant $(20.05 \mathrm{~g})$ and weight of mature pods/plant $(18.55 \mathrm{~g})$ and minimum \% of leaf area diseased than Bavistin in groundnut and also with Hannan et al. (2011) who observed the effectiveness of BAU Bio-fungicide for the foot rot disease of chickpea under field condition and found an excellent increased yield in his experimental field.

\section{Percent reduction of anthracnose infection of soybean against different treatments}

The highest \% reduction of infected plants/soybean plot was observed in treatment $\mathrm{T}_{5}$ (Bavistin @ 2\%, two spray) $76.25 \%$ followed by treatment $\mathrm{T}_{4}$ (BAU-Biofungicide @ 2\%, two spray) $62.61 \%$, treatment $\mathrm{T}_{2}$ (IPM Lab Biopesticide @ 2\%, two spray) 48.17\%. However, the lowest \% reduction of infected plants/plot was found in $\mathrm{T}_{1}$ (IPM Lab Biopesticide @ 2\%, one spray) (20.07\%) (Figure 1). These findings supported by Mostofa (2009) who found remarkable reduction of Cercospora leaf spot, Rust and Anthracnose disease severity in soybean were observed in seed treatment with BAU-Biofungicide and foliar spray of Bavistin @ $0.1 \%$ followed by seed treatment with BAU-Biofungicide and foliar spray of BAU-Biofungicide @ $2 \%$.

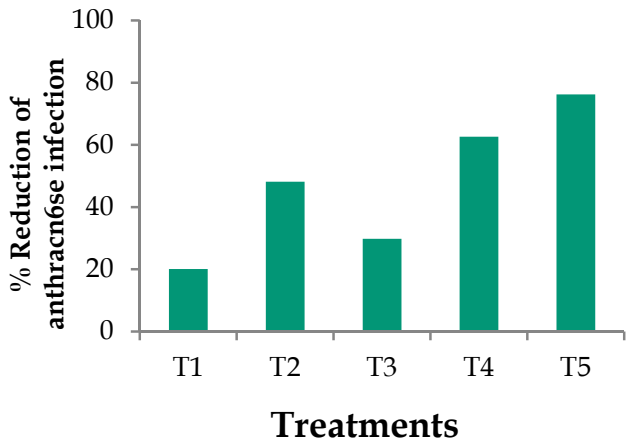

Figure 1. Percent of reduction of infected plants/plot over control

\section{Percent increased yield (ton ha-1) over control}

The percent increased yield (ton ha ${ }^{-1}$ ) over control is presented in Figure 2 . The highest $\%$ increased yield was $(246.06 \%)$ over control was observed in treatment $\mathrm{T}_{4}$ (BAU-Biofungicide @ 2\%, two spray) followed by treatment $\mathrm{T}_{2}$ (IPM Lab Biopesticide@ @ \%, two spray) (173.33). However, the lowest \% increased yield (23.03\%) over control was found in treatment T1 (IPM Lab Biopesticide @ 2\%, one spray) (Figure 2). These findings are in an agreement with Hossain (2003) who reported that the yield of vegetables and pulses can be increased by 25 to $80 \%$ over the untreated control by using BAU-Biofungicide.

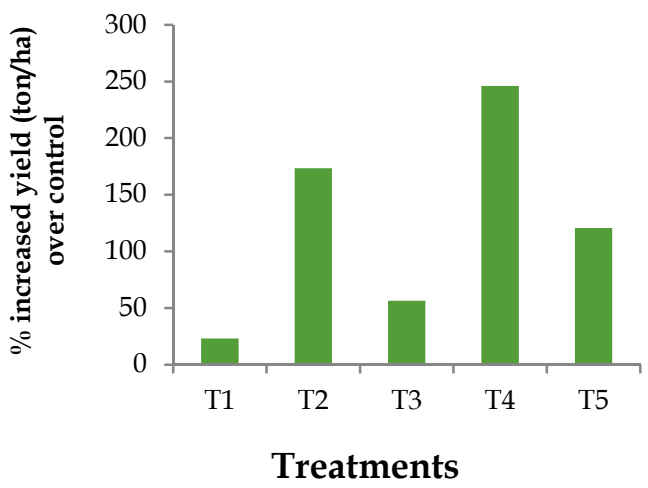

Figure 2. Percent increased yield (ton ha ${ }^{-1}$ ) over control 
The findings of the present study indicate the efficacy of BAU-Biofungicide over IPM Lab Biopesticide and Bavistin in promoting both vegetative and reproductive growth of soybean and in reducing incidence of anthracnose of soybean. BAU-Biofungicide may have some antagonistic activities that inhibit or suppress the growth of Colletotrichum dematium var truncatum.Jaime Alioscha Cuervo-Parra et al. (2011) stated that, $T$. harzianum VSL291 produced lytic enzymes: $\beta$-1, 3-glucanases, chitinases, proteases, xylanases and lipases, when grown in minimal medium, with fungal cell walls as the sole carbon source. The highest proteolytic activities detected in T. harzianum VSL291 broth with M. roreri, Penicillium expansum and Byssochlamys spectabilis cell walls appear to be associated with increased activities of 1, 3 glucanases, chitinases, lipases, proteases and xylanases and bio-control index derived from the experiments of confrontation. These results suggest that proteolytic enzymes according to their degree of induction could participate in the antagonistic effect of $T$. harzianum VSL291 against the fungi tested. Harman et al.(2004) reported that The presence of T22 (a strain of Trichoderma herzianum) increased protein levels and activities of $\beta-1,3$ glucanase, exochitinase, and endochitinase in both roots and shoots, even though T22 colonized roots well but colonized shoots hardly at all. With some enzymes, the combination of T22 with $P$. ultimum gave the highest enzymatic activity. On the other hand, plants grown from T22-treated seed had reduced symptoms of anthracnose following inoculation of leaves with Colletotrichum graminicola, which indicates that root colonization by T22 induces systemic resistance in maize. These previous results suggested that the application of Trichoderma herzianum might promote the activity of some defence related protein such as $\beta-1,3$ glucanase, exochitinase, endochitinase, peroxidases etc. in plant body. This biological agent also promotes the function of some cell wall degrading enzymes such as chitinases, proteases, xylanases which could degrade the cell wall of Colletotrichum dematium var truncatum infected soybean plants.

In addition, Shoresh et al. (2008) stated that Trichoderma spp. are effective bio-control agents for numerous foliar and root phytopathogens, and some are also known for their abilities to enhance systemic resistance to plant diseases as well as overall plant growth. In their study they also found that some proteins were up-regulated in shoot and root after application of $T$. harzianum strain T22 on roots which are involved in carbohydrate metabolism and photosynthesis activity. Increasing in these protein classifications suggests enhanced respiratory and photosynthetic rates. These changes may be required for the enhanced growth response induced by colonization of Trichoderma following seed or soil treatments. These findings also indicate that foliar treatment might also enhances the activity of proteins related to carbohydrate metabolism and photosynthesis activity and systemic resistance of plants.

\section{CONCLUSION}

The result of the present study indicates that the BAU-Biofungicide (Trichoderma harzianum suspension) showed better result compared to the IPM Lab Biopesticide in reducing incidence of anthracnose of soybean and promoting both vegetative and reproductive growth of soybean. This result might indicate that foliar application of Trichoderma harzianum in soybean plants might triggers some defence related and cell wall degrading proteins which can suppress the growth and degrade the cell wall of Colletotrichum dematium var. truncatum and some enzymes related to carbohydrate metabolism and photosynthesis activities and these physiological activities very much related to plant growth and development. BINA soybean-1 variety performed lowest disease incidence and highest yield than the other four soybean varieties used in this study, it might be due to its physiological and morphological features.

The present experiment was conducted for one season (rabi season) in a limited scale. So, this study needs to be carried out under different agro-ecological zones in the country before drawing a sound conclusion. However, farmers can be advised to use two times spray of BAU-Biofungicide with 15 days interval and variety BINA Soybean-1 to fulfill the requirement of biological control of anthracnose of soybean with maximum benefit (yield). 


\section{REFERENCES}

1. Annual report, 2012: Determination of optimum spacing and seed rate for growth and yield of soybean lines, Bangladesh Institute of Neuclear Agriculture. pp. 286-287.

2. Ansari MM, 1995 Control of sheath blight of rice by plant extracts. Indian Phytopathology, 3: 268-270.

3. Botta G, Annone J and Ivancovich A, 1994. Predominance and importance of anthracnose of soybean in the Northern Buenos province Argentina. Abst. Papers, Soybean Wrold Conference V. pp. 11.

4. Cuervo-Parra J A, Ramirez-Suero M,Sanchez-Lopez $V$ and Ramirez-Lepe M, 2011. Antagonistic effect of Trichoderma harzianum VSL29 on phytopathogenic fungi isolated from cocoa (Theobroma cacao L.) fruits.African Journal of Biotechnology, 10: 10657-10663.

5. Hannan M. A., Hasan M. M., Hossain I., Rahman S. M. E., Park M. S., Oh D. H. 2011. Integrated management of foot-rot disease of chickpea under field condition. JournalAgricultural Science Chungbuk National University, 27: 215-220.

6. Harman G E, Petzoldt R, Comis A, Chen J, 2004. Interactions between trichoderma harzianum strain t22 and maize inbred line Mo17 and effects of these interactions on diseases caused by Pythium ultimum and Colletotrichum graminicola. Phytopathology, 94: 147-53.

7. Hasan MM, 2012. Biological control of leaf of groundnut, MS thesis, Department of Plant Pathology. Bangladesh Agricultural University, Mymensingh, Bangladesh. pp. 7.

8. Hossain I, 2003. Use of BAU-Biofungicide to control seed borne diseases of vegetables and pulses. Agricultural Technologies, Bangladesh Agricultural University, Mymensingh. pp. 18.

9. http://www.bina.gov.bd/index.php?option=com_content\&view=article\&id=78\&ltemid=92.

10. Hymowitz $T$ and Shurtleff WR, 2005. Debunking soybean myths and legends in the historical and popular literature. Crop Science, 45: 473-476.

11. Islam T, 2009. Population dynamics of Phomopsis vexans, Sclerotium rolfsii, Fusanium oxysporum f.sp lycoperci and Trichoderma in the soil of eggplant field, MS thesis, Department of Plant Pathology, Bangladesh Agricultural University, pp. 48-57.

12. McGee DC, 1992. Soybean diseases. A reference source for seed technologist. APS press. The American Phytopathological Society St. Paul, Minnesota, USA. Napoles M. C., Guevara E., Montero F., Rossi A., Ferreira A. 2009. Role of Bradyrhizobium japonicum induced by genistein on soybean stressed by water deficit. Spanish Journal of Agricultural Research, 7: 665-671.

13. Osho SM, 2003. The Processing and Acceptability of a Fortified Cassava-based Product (gari) with Soybean. Nutrition and Food Science, Vol. 33, No.6.

14. Oyekan PO, 1985. Report of the nationally coordinated research projects on soybeans. Proceedings of the Fifth National Meeting of Nigerian Soybean Scientists, Publication, 5: 7-9.

15. Rahman Z, 2007. Biological control of sheath blight of rice using antagonistic Trichoderma, MS Thesis. Department of Plant Pathology, Bangladesh Agricultural University, Mymensingh. pp. 1-58.

16. SAIC 2007. SAARC Agricultural Statistics of 2006-07. SAARC Agric. Inform. Centre, Farmgate, Dhaka-1215. pp. 23

17. Satter MA, 2001. Biofertilizers in Bangladesh: Problem and prospect. In: Proc. $3^{\text {rd }}$ Nat. Wrokshop on Pulses, 11-12 June, 2001. BARC, Farmgate, Dhaka-1207. pp. 95-102.

18. Shoresh M, Harman G E, 2008. The relationship between increased growth and resistance induced in plants by root colonizing microbes. Plant Signal Behaviour,3: 737-9.

19. Sinclair JB, 1994. Reducing losses from plant disease. World soybean research conference V. abstracts. 10p. 